R. Histórla, São Paulo, n. 123-124, p. 143-219, ago./jul., 1990/1991.

HARO, Martin Afonso Palma de (organizador). Ilha de Santa Catarina Relato de viajantes estrangeiros nos séculos XVIII e XIX. Florianópolis: Editora da UFSC/Editora Lunardelli, 1990, $3^{\mathrm{a}}$ ediçăo.

\title{
Laima Mesgravis**
}

A obra aqui resenhada é uma coletânea de textos de viajantes estrangeiros que aportaram à Ilha de Santa Catarina de 1712 a 1828 já em sua $3^{a}$ edição $\left(1^{\mathrm{a}} 1979 ; 2^{\mathrm{a}} 1984\right)$ o que evidencia boa aceitação. Apesar da exiguidade de alguns relatos com poucas e vagas informações a exuberância de outros compensa pela abundância.

A leitura cronológica dos textos dos navegadores como Frezier, Anson, La Perouse; de cientistas como Langsdorf, Lesson permite até perceber o crescimento do povoamento da ilha de alguns poucos e assustados habitantes em 1712 para uma cidade comercial e portuária de certo relevo em 1828. Transparecem ali também os interesses das grandes potências da época como a França e a Inglaterra empenhadas no controle desse ponto de aprovisionamento e reparos de frotas que buscavam o Pacífico. Tudo indica que enquanto não foi construído o Canal do Panamá, Santa Catarina foi um dos pontos estratégicos do Atlântico Sul.

Fica também a imagem encantadora das descrições paisagísticas da ilha antes das depredações do século XX.

É de se lamentar, contudo, a falta de uma introdução e notas de um historiador especialista na história da ilha e do estado de Santa Catarina que poderia esclarecer a correspondência entre as localidades e os fatos citados pelos viajantes e os reais. Apesar da singeleza dessa edição a iniciativa é louvável e esperemos que seja seguida pela publicação dos textos referentes ao continente.

* Prof do Departamento de História/USP (aposentada)

* Prof ${ }^{\circ}$ Colaboradora UNESP/Franca 